\title{
Ben Okri's The Famished Road in the Context of Post- War West African Literature in English
}

\section{Philip Whyte}

\section{(2) OpenEdition \\ 1 Journals}

Electronic version

URL: https://journals.openedition.org/ces/5317

DOI: $10.4000 /$ ces.5317

ISSN: 2534-6695

Publisher

SEPC (Société d'études des pays du Commonwealth)

\section{Printed version}

Date of publication: 1 April 2013

Number of pages: 9-19

ISSN: 2270-0633

\section{Electronic reference}

Philip Whyte, "Ben Okri's The Famished Road in the Context of Post-War West African Literature in English", Commonwealth Essays and Studies [Online], 35.2 | 2013, Online since 17 April 2021, connection on 23 July 2021. URL: http://journals.openedition.org/ces/5317 ; DOI: https://doi.org/ $10.4000 /$ ces. 5317

\section{(c) (i) $\odot$}

Commonwealth Essays and Studies is licensed under a Licence Creative Commons Attribution - Pas d'Utilisation Commerciale - Pas de Modification 4.0 International. 


\section{Ben Okri's The Famished Road \\ in the Context of \\ Post-War West African Literature in English}

On publication in 1991 Ben Okri's The Famished Road was considered as a new departure in West African Anglophone fiction. This paper will seek to establish the novelty of the work by relating it to the literary and socio-political context out of which it emerged. This will lead to an examination of the evolution of the African writer's role against the swiftly evolving and increasingly conflictual background of contemporary postcolonial studies.

On publication in 1991, The Famished Road was greeted with some surprise by commentators familiar with West African literature in English. Not only did it mark a break from the largely realist mode of Okri's two previous novels (Flowers and Shadows and The Landscapes Within), but its recourse to "magic" elements, though redolent of earlier works on the lines of Amos Tutuola's re-creation of Yoruba folktales $(1953,1954)$, seemed nevertheless to point in the direction of a new departure. In a desperate attempt to classify a text articulated on an apparently seamless combination of aesthetic codes inspired by both the Western realist tradition and the "magic" dimension of African orality, some commentators somewhat hastily sought to relate Okri's novel to that quintessentially postmodernist category of "magic realism," best illustrated in the postcolonial tradition by Gabriel Garcia Marquez's One Hundred Years of Solitude and Salman Rushdie's Midnight's Children.

This conflation of aesthetic productions from widely different regions of the world may be seen as symptomatic of a certain tendency on the part of postcolonial studies to reduce the cultural productions emerging from colonization to a relatively limited number of concepts - hybridity as opposed to purity, the margins as opposed to the centre - which do not do justice either to the specificities of each writer's imaginative impulses or creative strategies or to the historical perspectives or context of production which shape their work.

As the Russian formalist Tynianov pointed out, a literary work belongs to an autonomous series made up of the verbal representations which came before it within the context of a tradition which it may seek to transcend, but which it cannot comfortably ignore. At the same time, the writer's individualist urge to give expression to his perception of the world around him inevitably comes up against a number of considerations which, in a sense, orientate his work even as he may try to resist, or at least control, the pressures being exerted on him from the outside. These considerations surround his own position within his society as well as the micro- and macro-histories of his people or nation of origin. They also include such features as the artist's status within a given group at a specific historical period, or issues pertaining to the social and cultural forces which determine the criteria which, in a given society, establish the way artistic representations are both perceived and received, not to say "consumed" (to use a vulgar Marxist term).

Bearing this is mind I will seek to show how The Famished Road is inscribed within a recognizable tradition of West African writing even while it explores the possibility of fresh departures. In a sense the uncanny feature of the novel lies precisely in the way it 
goes through, or over, a number of elements already familiar to readers of earlier African fiction while orienting them in a new, somewhat disconcerting, direction.

In keeping with the method briefly outlined above, I will suggest that this evolution is connected to Okri's strong perception of the tradition in which he is working but also to his own very personal conception of his function as a writer. At the same time, this evolution cannot be separated from the larger historical, aesthetic and theoretical issues bearing on the role of the African artist within the context of a world exposed in almost exponential fashion to the forces of change.

On this basis I am first going to examine the situation of Anglophone West African writing as Okri would have found it when he began his literary career in the 1980s, bearing in mind both the aesthetic and extra-literary forces which together provide the general context of production and reception of these works. I will then seek to show to what extent Okri's writing, notably with The Famished Road, both contains and transcends this body of writing by seeking to respond to the new interrogations emerging in the increasingly problematic field of so-called postcolonial literature and theory in the 1990s.

In a collection of essays published in 1997, Derek Wright divided Anglophone African writing between the 1950s and 1990s into four phases (5-10): the 1950s/early 60s "writing-back" colonial narratives aimed at countering the Western monopoly on representations of African history, the post-independence "disenchantment" novels of the late 1960s and early 1970s, the late 1970s polemical attempt to break with the West by returning to a more "authentically" African aesthetic, and finally the experimentation with new forms occurring in the 1980s and 90s. To summarize to the point of appearing simplistic, each phase can be related to one representative work: the first to Chinua Achebe's Things Fall Apart (1958), the second to Ayi Kwei Armah's The Beautyful Ones Are Not Yet Born (1968), the third to Armah's Two Thousand Seasons (1973) and the fourth to Okri's The Famished Road (1991).

Beginning in the late 1950s Wright's classification leaves no room for writers who began their careers in the 1940s (though continuing well beyond this point) whether in the field of so-called "market literature" (Benibegnor Blay, Asare Konadu, E. A. Mickson) or that of folktale (Amos Tutuola). As recent studies have indicated (Priebe, Newell), the popular novelists for so long ignored by professional scholars had a far greater impact on the new reading public coming into being in Nigeria and Ghana just before and after the independence period than those writers officially acclaimed in the West as the true representatives of contemporary African literature. This point can, however, be left aside for the purpose of this discussion in so far as the popular writers do not appear to have exerted a noticeable influence on Okri's own aesthetic choices. True, his early novels, in particular, indicate an awareness of social issues largely connected to the necessity for a new generation of Africans to adapt to an increasingly urbanized society. However, this concern constitutes too big a topos in contemporary African literature to act as the sign of a clear filiation.

More significantly, Wright's summary also eliminates Amos Tutuola, the Nigerian writer whose novels The Palm-Wine Drinkard (1953) and My Life in the Bush of Ghosts (1954) burst onto the international literary scene in the mid-1950s as representative of a distinctive African voice and world-view with the consequence, as Dylan Thomas and Raymond Queneau claimed at the time, of revolutionizing both the form and content 
of world literature. Though it is now usually accepted with hindsight that Tutuola's nonstandard English has less to do with Joycean experimentation than with the use of a kind of language conventionally taught at Standard Four in Nigerian senior primary (or elementary) schools (Orban 4), the impact of this novel on Okri's work is too evident to be ignored.

Tutuola's writing can indeed serve as a useful yardstick for measuring the changes occurring in West African fiction during the period under examination, not only in linguistic (or rhetorical) terms but also in relation to the African writer's need to represent a new perception of reality which can rescue some coherence out of the potential chaos introduced by the rapid, but also highly irregular, intrusion of modernity into a largely traditional framework. By restoring Tutuola's place in the first phase of post-war Anglophone West African literature, the three following stages mentioned by Wright can then be seen as developing organically out of the need to come to terms with a constantly evolving situation. The axis of this evolution is largely provided by the way the writers concerned filter experience through narrative strategies which play on the problematic relationship existing between a traditional apprehension of reality and a perception more attuned to the type of rationalism associated with a more technologically or scientifically orientated society.

From this point of view, the first stage occupied by Tutuola is clearly that of the pre-scientific universe of traditional epic and folktale. His novelty does not lie in the content of his stories so much as in the fact that he is the first West African writer, after Fagunwa, to seek to express these in writing. This formal concession to change is compounded by the fact that, unlike Fagunwa, he chose also to have recourse to the English introduced into the elementary school system by the colonizer. It is perhaps this disparity between traditional content and modern vehicle which explains the failure of Tutuola's first novels with an audience at that time more attuned to the urban novelettes mentioned before (Ricard 91).

Tutuola's awareness of change is clearly visible in the presence of objects emblematic of Western technology (the TV set of My Life in the Bush of Ghosts, 163) as well as events directly connected with recent Nigerian history. Among these we may mention explosives (West African soldiers had fought with the British army in Burma) and oil barrels (pointing to the main new source of Nigeria's wealth). However, in keeping with the observations made by anthropologists concerning the Yoruba capacity to integrate the technological paraphernalia of modernity into a traditional world-view (Drewal, Apter), these objects do not in any way perturb the homogeneity of Tutuola's universe. As Bernth Lindfors has pointed out (69), the TV set embedded in the palms of a mysterious goddess is not presented as an emblem of technological prowess but, on the contrary, appears integrated into the established ceremonial of a divinity ritual. Similarly, the oil barrels of The Palm-Wine Drinkard lose some of their referential status by being reduced simply to metaphors for the rolling skulls of the spirits whose presence is clearly more relevant to the narrative.

For the rest, Tutuola's novel, while revelatory of the author's exceptional inventiveness, has recourse to the whole gamut of literary devices which, on both the formal and structural levels, inscribe it within the oral tradition of epic and folktale. If we limit ourselves to the most famous episode in the novel, known as "The Complete Gentleman," we may first mention the quest motif and the conventional tripartite structure ac- 
companying it: the drinkard's rescue of the girl follows the pattern of a departure from the town, a confrontation with the spirits in the forest and a triumphant return. Epic exaggeration is subjected to the traditional rhetorical device of incremental repetition, as the gentleman's progress through the forest is measured in the form of constantly increasing distances. Most importantly, Tutuola, like the popular "market" writers, adheres without reserve to the didactic and pragmatic aim of traditional African art, going so far as to present the young girl's trials (she is kidnapped by the handsome gentleman after refusing the husband chosen by her father) in the form of a maxim: "do not follow unknown man's beauty" (202).

The second phase, characterized by the realist mode adopted by Chinua Achebe and his innumerable followers, marks a definite shift in the way the traditional world is presented. In keeping with the strategy of "writing back" referred to above, Achebe's explicitly pedagogical aim was to provide a narrative of African (more precisely Ibo) history from the inside so as to counter the representations monopolized until then by Western "outsiders" such as Joseph Conrad (Heart of Darkness), Joyce Cary (Mister Johnson) and Lord Lugard, the first Governor of Northern Nigeria, whose account of local "tribes" is evoked indirectly at the end of Things Fall Apart (148).

Unlike Tutuola, who projects the reader without any preparation into a traditional universe of spirits, demons and mysterious forests, Achebe's pedagogical enterprise, notably in Things Fall Apart, obliges him to reconstitute a world whose cultural, socio-economic and political complexities have simply been brushed aside by Western accounts to the point where many Africans themselves no longer have a clear view of their own heritage. This obliges him to lace his story with large amounts of anthropological detail aimed at reconstituting and illustrating the intricacies of the traditional world. However, this wealth of background detail is unobtrusive in so far as it is skillfully integrated into the novel's symbolic structure. It is precisely because Okonkwo has fully interiorized his people's traditional beliefs that he ultimately becomes a threat to their well-being. By refusing a Manichean confrontation between the traditional and the new, Achebe opts for a realist aesthetic best attuned to representing the complexities of a society in transition.

His wish to give visibility to the subtle process whereby tradition is absorbed into modernity leads him to adopt a mode of representation which, to my mind, defines the second phase of West African literary evolution as described above. In this phase the author exploits the full potential of authorial reticence to toe an extremely fine line between the presentation of a traditional universe inhabited by spirits and deities and the modern world of scientific causality. In its most clear form, as illustrated by Achebe's short story "The Sacrificial Egg" (1972), this technique, referred to by Roger Chemain (71) as "dual causality," enables the author to present a complex universe where the old and the new co-exist, thereby preserving the immediacy of a dual apprehension of reality specific to peoples subjected to a sudden projection into newness.

Julius Obi, the story's central character, literally has a foot in both worlds, as illustrated immediately by his Afro-Western name. Born in a traditional "bush village," he has had a Christian mission school education and now occupies a subaltern position within the modern economy as a clerk in an export-import company. Though wary of traditional beliefs ("[his] education placed him above such suspicious stuff," [239]), he is nevertheless sufficiently close to the traditional world to be clearly affected by his future mother-in law's references to the water divinities ("mammy-wota") who, according to her, 
mingle freely with ordinary people at the market. In West African belief the market is a conventional meeting-place (together with crossroads) for the spirit and human worlds (Drewal 26).

Julius's contradictions reach a head at the story's close when he steps on an egg strategically placed at a crossroads as protection against the "evil deity" Kitikpa whose wrath has inflicted a deadly illness throughout the town. Convinced he has thus attracted the god's ire onto himself, Julius hides for his life as he hears the spirit rush by him in a pandemonium of footsteps and "esoteric" shouting.

Authorial reticence is present throughout the narrative in the form of a series of distancing remarks which place the omniscient narrator on the margins of the world described: "it was said that [the market deity] appeared in the form of an old woman," "it was as if twenty men were running together" (238, 240, italics mine). However, the occasional shifts into internal focus give full force to the religious angst felt by Julius as his scepticism crumbles beneath the weight of a perception of reality instilled in him by the bush village environment into which he was born. This ambivalence is neatly embodied in the novel's close where the scientific explanation of events - the people are the victims of small pox - is set off against Julius's brutal awareness that his clumsiness may be the reason why his fiancée Janet is among the victims.

The problematic relationship between traditional and scientific representations of the world undergoes another shift when we examine the third phase referred to by Derek Wright. As illustrated by Armah's Two Thousand Seasons (1972), this phase, corresponding to the disenchantment felt by an entire generation at the failure of political independence to shake off the economic and spiritual domination of the West, is characterized by a strong radicalization of the tendencies found before. Not content with providing a counter-vision of their histories, writers will now seek to achieve an aesthetic break which, in the case of Armah, will lead to a direct contestation of the realist codes of the Western novel. In Two Thousand Seasons, a historical account of the Akan people's migration from the medieval empires of the Sahel down to the Gulf of Guinea (the location of present-day Ghana), he has recourse to an epic form of declamation in the manner of the traditional griot, incorporating the oratorical and mnemotechnical devices of orature into a written text.

Given this strategy, the reader is not surprised to find himself in a world free from the logic of scientific causation, no more than if he were reading epic texts from other traditions. Moreover, he soon becomes aware that Armah's unabashed assumption of a traditional world-view is important only in so far as it is incorporated into a generalized onslaught on Western conceptions of the universe whose polemics find their source in Frantz Fanon's radical theories on colonial emancipation $(1952,1961)$. True to the cultural nationalism whose influence in the 1970s developed in response to the new African elite's fascination for their former leaders, the magic world is in effect reduced to one of several narrative components making up a strongly Manichean structure which pits an authentic African "way" against a collective evil represented by "white" intruders from the north, whether Arab or European. The surprise an inexperienced reader may first feel on reading this text (Fraser 64) is thus partly neutralized by a narrative which, in keeping with the practice analyzed by Susan Rubin Suleiman (1983) as typical of the "authoritarian novel," methodically seeks to submit all the codes which make up the text (Barthes 35sq.) to the expression of a transparent message. From this point of view, 
Armah may be said to have gone even further than Achebe in his desire to put his work in tune with the pragmatic, heuristic tradition of African art.

If one bears these successive phases in mind, The Famished Road can be construed as continuing in the footsteps of what came before, the fundamental difference being that Okri's novel tends to blur the distinction between the dominant codes which we have taken as the defining feature of each of the phases examined. The first (Tutuolean) phase is clearly present in the constant references to peculiar creatures: a man with his face "upside down," (65) people without eyes (107), a "floating" woman with a blue head (307). Embracing this traditional idiom, Okri also alludes to the process of incremental repetition with the successive arrival of spirits equipped with an ever-increasing number of heads (303). Finally, mention may be made of such features as wrestling matches, notably the epic fights between Dad and his formidable adversary Yellow Jaguar (355-6), and later the white-suited man (473) which constitute a recurrent feature of the oral tale.

Against this, however, large sections of the novel appear to adhere to a code of verisimilitude more in keeping with the second phase associated with Achebe. Within this perspective, events which initially appear as manifestations of the marvelous are in effect given a more rational basis in keeping with the dual causality technique mentioned above. When Azaro sees a young girl melting into a cauldron of soup, this is related to the fact that he has already been made dizzy by the smoke in Madame Koto's kitchen (207). Throughout the novel, the universe is largely filtered through the gaze of the young Azaro, a "small boy" (261) whose fascination even for relatively ordinary objects - the exotic wares of a Hausa trader (201), the multiple tools in a carpenter's workshop (370) - may be assimilated to the process of discovery inseparable from the process of growing-up.

This controlled ambivalence is perhaps most evident in the long central sequence (325-39) where Azaro's journey in the company of the three-headed spirit is constantly presented in counterpoint with his parents' attempts to draw him out of a feverish coma. At one point Azaro even appears to assume fully the perspective of a more realist standpoint, as when his irritation against the villagers' tendency to interpret all events as manifestations of the supernatural (in this instance their belief in Madame Koto's ubiquity) makes him yearn for the return of the photographer who alone can put an end to what he here refers to as the "delirium of stories" (182).

However, this realist stance is not sufficiently consistent to be accepted as the novel's defining mode as there are times when it is simply brushed aside by what seems to be a fully unabashed acceptance of the Tutuolean vision. When we learn, for example, that Yellow Jaguar has been dead for three years before the fight with Dad (358), no explanation is offered to the contrary. More strikingly, no narrative distancing can be seen in the evocation of the metamorphosis of the white-suited man into an insect (473), an episode which refers back explicitly to Tutuola's tale of the "complete gentleman," the beautifully dressed man who gradually turns into a skull.

This apparent tendency on Okri's part to play with different narrative codes is apparent also if we examine his novel in relation to the third phase mentioned before. Although no attempt is made, unlike in Two Thousand Seasons, to reproduce the idiom of orature, The Famished Road does appear at times to embrace the political polemics which serve as one of the principal characteristics of the "disenchantment" generation. Politi- 
cal corruption is evidenced by the rotten milk distributed by the political parties in their demagogic struggle to buy the people's votes (155) and Okri's representation of the Party of the Rich with its affluent "businessmen, contractors (and) exporters" dressed in Western-style "safari suits" (220) appears to be modeled on Armah's own attacks on the new African élite, the comprador class of "merchants and lawyers" (The Beautyful Ones 81, 83) denounced also by Fanon and Ngugi wa Thiong'o (304) as the true betrayers of the ideals of independence. This form of political denunciation even expands into a pan-African vision encapsulating, through the photographer Jeremiah, the horrors of discrimination in South Africa and the American Deep South (263).

Here too, however, it would be difficult to read Okri's novel as a vehicle designed to convey a clear political message. In Armah and Ngugi the Fanonian call for the definition of an authentic African "way" capable of making a decisive break with Western models is proclaimed decisively via two elements considered in structuralist criticism (Greimas 68) as central to authoritarian fiction: an encoded authorial voice representing the author's position and an antagonistic (or Manichean) symbolic system opposing the positive message to the negative one. Where such a voice appears to exist in Okri's novel, as in the account of the valley people's heroic attempts to re-build a road constantly destroyed by the elements (330sqq.), the value of the message is more than blurred by being uttered by the three-headed spirit who is busy at that moment dragging Azaro away from his parents! Similarly, the premises of a Manichean structure, apparent in Dad's constantly growing commitment towards helping the more disenfranchised sections of the population against Madame Koto's correspondingly enthusiastic support for the powerful, points less to a political solution (the Party of the Poor are constantly shown as no better than the Party of the Rich) than to a moral combat on the lines of traditional African fiction. From this point of view, it may be possible to suggest that the repeated postponement of the nation's independence, announced quite early in the novel but still not effective several hundred pages later at the conclusion of the series' second sequel (Infinite Riches), is a sign that the tensions represented cannot be played out on the political level, a point which distinguishes Okri from most of the authors writing in the 1970 s.

Having suggested that The Famished Road is thus characterized by the problematic manner in which it both incorporates and distances itself from the earlier works, we should now seek to go a little further and examine a number of hypotheses capable of providing answers as to the reasons why the author has opted for these narrative and formal choices.

One common reading of the work is provided by those commentators who, in the critical tradition established notably by Homi Bhabha, consider that Okri belongs to a generation which can no longer satisfy itself with a binary view of postcolonial relations, aware as it is of the growing cultural hybridity imposed by massive population movements and the international flow of consumer products. Seeing themselves as called upon to give voice to an increasingly complex situation characterized by the telescoping of the ancient and the modern, these writers no longer consider it necessary to tread delicately on the borderline separating traditional/magic and modern/realist representations of the universe and revel instead in an aesthetics articulated on what Amaryll Chanady, in her definition of magic realism, has referred to as "the juxtaposition of two mutually exclusive codes" (29sqq.). 
From this perspective Okri is all too quickly assimilated to writers like Salman Rushdie, whose joyful mingling of the rational and the irrational, the stuff of legend and the grim realities of the present, is clearly associated with the need to represent what Rushdie (4) calls the "mongrelisation" of a world subjected through socio-economic and cultural globalization to ever more powerful centrifugal pressures.

Certainly, Okri's novel underscores the manner in which urban "skyscrapers" are gradually displacing a village society based on "mud huts" (113), an apparently inexorable process illustrated by the way Western technology enters the villagers' lives in the form of new transport (the car, 380), new lighting (electricity, 373), new drinks (Coca-Cola, 215) and new ways of apprehending the world (as indicated by the way the camera's flash sends the spirits plunging to the floor, as if in defeat, 45). According to this reading, Okri would thus be part of a new generation which has in effect come to terms with the commingling of opposite worlds. Transcending the authorial reticence of their predecessors, for whom the relationship between the traditional and the modern is clearly problematic, these writers give full voice to their apprehension of a complex reality, with the author occupying a central strategic position as the vehicle for a multifaceted view. Okri's choice of an abiku narrator, a child literally with one foot in the spirit world and one in the world of everyday reality, is thus perfectly in keeping with his decision to present both realities simultaneously.

The association with Rushdie has, however, involved Okri in the bitter debate which swept through postcolonial studies in the 1990s between the disciples of Bhabha and his opponents in the neo-Marxist or cultural nationalist camp. The latter (including Arif Dirlik, Fredric Jameson and Aijaj Ahmad (cf. Cooper, 15sqq.) go so far as to accuse these writers of belonging to a cosmopolitan elite which is in a way cynically exploiting the exoticism of tradition to pander to the tastes of a largely Westernized audience. In so doing they feign to ignore the huge economic and cultural disparities superficially hidden by what appears to be the growing standardization imposed by the global circulation of products and lifestyles.

For lack of space, it is impossible here to enter into the details of this debate. However this point of view raises questions concerning the writer's role in West Africa in the aftermath of what we may refer to as the "hot phase" of the postcolonial struggle. Some fifty years after the constitution of an African Anglophone literary tradition, and some forty years after the end of the last explicitly colonial wars in the Portuguese colonies, the time may have come for African writers legitimately to question their role both as the recipients of a new canon of African writing and as the mouthpieces of their nations' political aspirations.

This may provide the impetus for two new readings of The Famished Road whose full development would require a far longer study. In terms of heritage, Okri seems at times to write as if one of his aims were to situate himself in relation to his predecessors' contributions, as if to take stock of what has been achieved since the emergence of Tutuola. From this angle the novel's innumerable allusions to earlier writers may be seen as partaking of the intertextual process whereby a tradition constitutes itself as a body of literature. This phenomenon, which I believe to be unique to the writers emerging in the late 1980s (notably Kojo Laing and Biyi Bandele-Thomas), is apparent, as we have seen, in the way Okri actually incorporates into his novel the literary codes used by Tutuola, Achebe and Armah. At other times the allusions are either all but explicit the parallel 
already mentioned between the suited wrestler and the "complete gentleman," the references to the destruction of an authentic African "road of two thousand years" [331] on the model of Armah's novel of that name), or are destined to incite a sentiment of recall in readers familiar with this body of writing. Thus, Madame Koto's monstrous embryos, representing a future Nigeria with "no intention of being born" (464) cannot but evoke the sickeningly menstrual images which provide one of the main symbolic clusters of Armah's The Beautyful Ones Are Not Yet Born, a novel largely informed by the wish to present the failure of Ghana's independence in terms of a monstrous still-birth. Similarly, the trauma of Azaro's nightmarish vision of some of the bleakest moments of Africa's history (457sqq.) vibrates with a specifically poignant resonance through its association with the duiker, "the best of animals, attacking none" (Armah Seasons, 57) whose death in Two Thousand Seasons (112) epitomizes the despair felt by the future slaves on their journey to the ocean.

Having said this, Okri's quasi choric homage to his predecessors goes on a par, as we have seen, with his refusal to place his novel within the aesthetic framework of each of the writers mentioned, thereby opening an experimental space which may also be considered a distinctive feature of this generation's conception of its authorial role. By both evoking and transcending the various modes through which West African fiction had been apprehended before the The Famished Road's publication - the magic world of Tutuolean folktale with its didactic inclinations, the heuristic re-evaluation of Ibo history in Achebe's novel sequence, the anticolonial Manichaeism of Armah's polemical epic - Okri appears to withhold the key which may help the reader to decipher his text at the very moment when he seems to be handing it to him.

This should enable us to draw attention to the central thesis contained in the first book-length study of Okri's writing (Fraser) concerning what seems to appear as a constant, almost defining, feature of his work: namely, a use of language which seeks as far as possible to turn away from the capacity of words to reduce, through excessive transparency, the complexities of reality, and a corresponding insistence on the evocative, poetic dimension of the verbal idiom. Whether in his critical works - the attack in $A W$ ay of Being Free (88) on the negative power of "words that reduce [meaning]," or in his fiction - the guide in Astonishing the Gods (1995) who informs the protagonist that it is mystery alone "which keeps things alive" (30) - Okri is bent on writing texts which invite a hermeneutics usually confined to the reading of poetry. As Brenda Cooper has pointed out (80), Okri's road, though a topos of African literature central to the work of the great Nigerian playwright Wole Soyinka (1965), is open to any number of interpretations.

However, what interests me here, over and above the actual deciphering of a largely opaque text characterized by a constant emphasis on metamorphoses, masks, changing realities and "riddles" $(75,427,488)$, is the manner in which this emphasis on difficulty seems to point to an important shift in the way African writers are now beginning to envisage their role, notably in relation to an indigenous readership. As with Biyi Bandele-Thomas's recourse to embedded texts and other metafictional devices in The Man Who Came in From the Back of Beyond (1992) or Kojo Laing's polyglossic experimentations in political fantasy or science fiction in Woman of the Aeroplanes (1986) and Major Gentl and the Achimota Wars (1990), Okri appears to consider that the time has now come for the African writer to express himself with the full freedom of the true artist. This atti- 
tude implies a shift away from the idea that the specific "responsibility" which writers from the former colonies have towards their people (Gordimer) should oblige them to remain within the bounds of a relatively straightforward aesthetics considered as sole capable of conforming to the expectations of the average reader.

Though political themes still loom large in the works of all these authors, their claim to express the world "as [they] see it" (Laing 104), and not according to the politically correct norms dictated by reader performance, goes on a par with the evolution of postcolonial theory in the direction of a more problematic and complex vision of postimperial relations (Bayart). From this point of view the opacity of The Famished Road is emblematic of this new phase in African literature.

\section{Philip WHYTE \\ Université François Rabelais - Tours}

\section{Works Cited}

ACHEBE, Chinua. Things Fall Apart. London: Heinemann, 1958.

—."The Role of the Writer in a New Nation." Nigerian Magazine 81 (1964): 27-35.

—."The Sacrificial Egg." Commonwealth Short Stories. Ed. A. RutHerford and D. Hannah. 1972. Hong Kong: Dangaroo P, 1979. 238-40.

APTER, Andrew. Black Critics and Kings: The Hermeneutics of Power in Yoruba Society. Chicago: U of Chicago P, 1992.

Armah, Ayi Kwei. The Beautyful Ones Are Not Yet Born. London: Heinemann, 1968.

—. Two Thousand Seasons. London: Heinemann, 1973.

Ashcroft Bill, Gareth Griffiths, and Helen Tiffin. The Empire Writes Back. London: Routledge, 1989. BARTHES, Roland. S/Z. Paris: Seuil, 1970.

BAYART Jean-François. "Les Etudes postcoloniales, une invention politique de la tradition?" Sociétés Politiques Contemporaines: revue de l'analyse des sociétés politiques 14 (avril 2009): 1-46.

Bendele-Thomas, Biyi. The Man Who Came in from the Back of Beyond. London: Heinemann 1992.

BнавнA, Homi. The Location of Culture. London: Routledge, 1994.

Chanady, Amaryll. Magic Realism and the Fantastic: Resolved and Unresolved Antinomy. New York: Garland Publishing, 1985.

ChEMAIn, Roger. L'Imaginaire dans le roman africain d'expression française. Paris: L'Harmattan, 1986.

CoOper, Brenda. Magical Realism in West African Fiction: Seeing with a Third Eye. London: Routledge, 1998.

Drewal, Margaret. Yoruba Ritual: Performance, Play, Agency. Bloomington: Indiana UP, 1992.

FAnON, Frantz. Peau noire, masques blancs. Paris: Seuil, 1952.

—. Les Damnés de la terre. Paris: Maspero, 1961.

Fraser, Robert. The Novels of Ayi Kwei Armah: A Study in Polemical Fiction. London: Heinemann, 1980.

—. Ben Okri: Towards the Inner City. Tavistock: Northcote House, 2002.

GordiMER, Nadine. La Responsabilité politique de l'écrivain." Le Monde Diplomatique janvier 1985: 22-4.

GREIMAS, André. Sémantique structurale. Paris: Larousse, 1966.

LaIng, Kojo. Woman of the Aeroplanes. New York: William Morrow and Company, 1988.

-. Major Gentl and the Achimota Wars. London: Heinemann, 1990.

-. "This Is Not a Paper." Anglophonia-Caliban: French Journal of English Studies. Ed. C. Fioupou. Toulouse: P U du Mirail, 2000: 103-6.

Lindfors, Bernth. Folklore in Nigerian Literature. New York: African Publishing Company, 1973.

Newell, Stephanie. Ghanaian Popular Fiction. Athens: Ohio UP, 2000.

NGugI wa Thiongo. "Decolonising the Mind: the Politics of Language in African Literature." Ed. A.

Doummergues. Le Commonwealth: histoire et civilisation. Nancy: PU de Nancy, 1991. 304-5.

OKRI, Ben. Flowers and Shadows. Harlow: Longman, 1980.

—. The Landscapes Within. Harlow: Longman, 1981.

—. The Famished Road. London: Vintage, 1991.

—. Astonishing the Gods. London: Phoenix House, 1995.

—. A Way of Being Free. London: Phoenix House, 1997.

Orban, Jean-Pierre. “Amos Tutuola, écrivain didactique." Africultures Septembre 2009: 20-5.

Priebe, Richard. "Popular Writing in Ghana: a Sociology and Rhetoric." Readings in African Popular Culture. Ed. K. BARBER. Bloomington: Indiana UP, 1997. 81-91.

SOYINKA, Wole. The Road. 1965. Oxford: Oxford UP, 1981.

Rushdie, Salman. In Good Faith. London: Granta, 1990. 
Ben Okri's The Famished Road in the Context of Post-War West African Literature in English

Suleiman, Susan Rubin. Le Roman à thèse, ou l'autorité fictive. Paris: PU de France, 1983.

Tutuola, Amos. The Palm-Wine Drinkard. 1953. New York: Grove Press, 1984.

—. My Life in the Bush of Ghosts. 1954. New York: Grove Press, 1984. 